\title{
Rare Association of a Myxoid Variant of Classical Conus Ependymoma with Holocord Syrinx
}

\author{
Kapoor $A^{1^{*}}$, Singla $\mathbf{N}^{2}$, Salunke $\mathbf{P}^{2}$, Chatterjee $D^{3}$ and Vashishta $\mathbf{R K}^{4}$ \\ ${ }^{1}$ Senior Research Associate, Department of Neurosurgery, PGIMER, Chandigarh, India \\ ${ }^{2}$ Assistant Professor, Department of Neurosurgery, PGIMER, Chandigarh, India \\ ${ }^{3}$ Senior Resident, Department of Histopathology, PGIMER, Chandigarh, India \\ ${ }^{4}$ Professor, Department of Histopathology, PGIMER, Chandigarh, India
}

*Corresponding author: Kapoor A, Senior Research Associate, Department of Neurosurgery, PGIMER, Chandigarh, India, Tel: +919914209419; E-mail: dr.ankurkapoor@gmail.com

Received date: Nov 27, 2015; Accepted date: Jan 19, 2016; Published date: Jan 21, 2016

Copyright: (C) 2016 Kapoor A. This is an open-access article distributed under the terms of the Creative Commons Attribution License, which permits unrestricted use, distribution, and reproduction in any medium, provided the original author and source are credited.

\begin{abstract}
Holocord syrinx associated with conus ependymoma is a rare entity. Commonly such ependymomas are located in cervical and dorsal regions with only few reports mentioning conus lesions having associated holocord syrinx. This variant responds well to surgery and long term prognosis is favourable. The associated syrinx does not need any specific treatment and does resolve by itself.
\end{abstract}

\section{Letter to Editor}

Intramedullary tumors make up $25 \%$ to $57 \%$ of all cases of syringomyelia, hemangioblastoma, astrocytoma and ependymoma making up for most of these [1]. Location of syrinx is most common in and around region of tumor. Holocord syrinx associated with conus ependymoma is a rare entity. We report a myxoid variant of such tumor with dense mucin and scarce papaillae and discuss the different mechanisms of its formation.

A 28 year male patient presented to us with complaint of backache and difficulty in walking for one year and urine incontinence for three months. On examination he had flacid paraparesis (grade 3/5), dissociated sensory loss to pain and temperature in bilateral upper limbs and spastic bladder dysfunction. Gadolinium magnetic resonance imaging (Gd-MRI) (Figure 1) revealed an intramedullary lesion at L1-L2 level with fusiform enlargement of cord and associated syrinx till C2. The lesion was isointense on T1W and hyperintense on T2W images. The patient underwent L1-L3 laminectomy. Gross total excision of tumor was achieved while no intervention was done for syrinx. Histopathology confirmed presence of papillary pattern of tumor cells, psedorosettes and Rosenthal fibres, overall consistent with ependymoma with myxoid changes (Figure 2). Immunohistochemistry was positive for GFAP and NSE.

Various etiologies are proposed for syrinx formation in intramedullary tumors as obstruction to cerebrospinal fluid (CSF) flow leading to cyst formation, direct transudation, exudation from vessels of tumor and disruption of blood brain barrier [1-4]. The dynamic communications between subarachnoid space and the extracellular space of the nervous parenchyma highlights the relationship between the two compartments in the pathogenesis of such cavitations.

Obstructions of the spinal canal result in transmission of the CSF pulse pressure through the cord and produce intramedullary pressure gradients. Some degree of CSF flow obstruction due to subarachnoid space obliteration is also seen as in Chiari malformation and spinal dysraphism. As a result of tumor hemorrhages or mechanical irritation, arachnoid scar may also be a contributing factor [5].

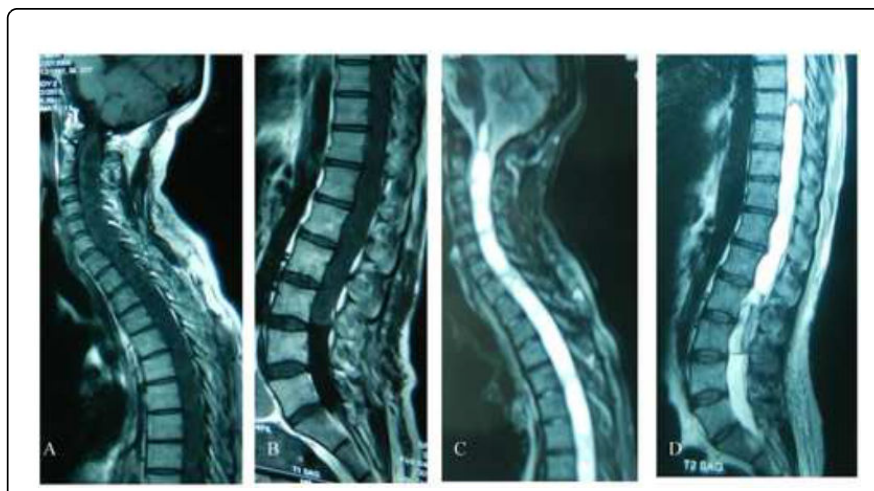

Figure 1: MR images showing intramedullary lesion at L1-L2 level which is isointense on T1W image with no enhancement $(\mathrm{a}, \mathrm{b})$ and hyperintense on T2W. Please note associated holocord syrinx.
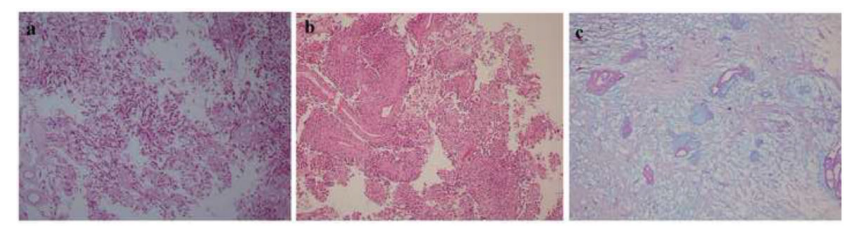

Figure 2: a. Photomicrograph showing a glial tumor with prominent perivascular pseudorosettes (HE, X4) b. few halinized blood vessels with myxoid change in the background (HE, X10). c. Myxoid change highlighted by Alcian blue staining (Alcian blue, X20).

Syrinx associated with intramedullary tumors has been reported to vary from $16.4 \%$ to $90 \%$ while in ependymoma per se it is reported to 
Citation: Kapoor A, Singla N, Salunke P, Chatterjee D, Vashishta RK (2016) Rare Association of a Myxoid Variant of Classical Conus Ependymoma with Holocord Syrinx . J Cytol Histol 7: 390. doi:10.4172/2157-7099.1000390

Page 2 of 2

be $9-50 \%[3,4]$. Polar cyst at cranial or caudal end is common feature in spinal ependymoma (78-84\%) but holocord syrinx is an uncommon entity $[2,4]$. Commonly such ependymomas are located in cervical and dorsal regions with only few reports mentioning conus lesions having associated holocord syrinx [6].

The myxoid variant of classical ependymoma is usually seen in young adults and common location is conus-cauda. MRI is the investigation of choice and demonstrates hypointense to isointense lesion on T1W and $\mathrm{T} 2 \mathrm{~W}$ image and heterogenous contrast enhancement [7]. Immunohistochemistry shows positivity for GFAP, NSE, CD99 and CD55. Imaging characteristics, histology and immunohistochemistry profile helps in proper diagnosis. This variant responds well to surgery and long term prognosis is favourable. The associated syrinx does not need any specific treatment and does resolve by itself.

\section{References}

1. Keung YK, Cobos E, Whitehead RP, Roberson GH (1997) Secondary syringomyelia due to intramedullary spinal cord metastasis Case report and review of literature. Am J Clin Oncol 20: 577-579.
2. Borkar AS, Satyarthee GD, Sharma BS (2009) Conus ependymoma with holocord syrinx. Neurol India 57: 353-354.

3. Lohle PNM, Wurzer HA, Hoogland PH, Seelen PJ, Go KG (1994) The pathogenesis of syringomyelia in spinal cord ependymoma. Clin Neurol Neurosurg 96: 323-326.

4. Sarikaya S, Acikgöz B, Tekkök IH, Güngen YY (2007) Conus ependymoma with holocord syringomyelia and and syringobulbia. J Clin.Neuroscience 14: 901-904.

5. Vicenzo G, Assietti R, Morosi M, Arienta C (2005) Acute brainstem dissection syringomyelia associated with cervical intramedullary neurinoma. Neurosurg Rev 28: 163-167.

6. Koeller KK, Rosenblum RS, Morrison AL (2000) Neoplasm of spinal cord and filum terminale: Radiopathologic correlation. Radiographics 20: 1721-1749.

7. Sun B, Wang C, Wang J, Liu A (2003) MRI features of intramedullary spinal cord ependymoma. J Neuroimaging 13: 346-351. 